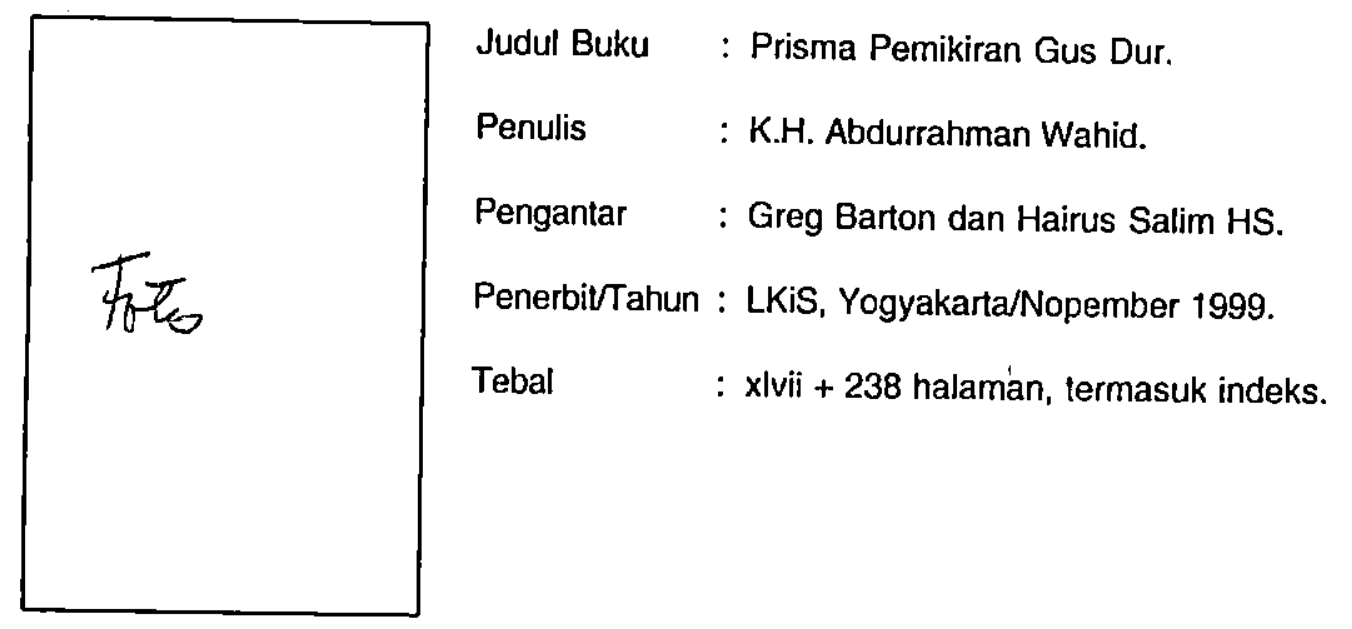

\title{
Buku Panduan untuk Mengamati Presiden Gus Dur
}

$\mathbf{A}$ da empat tulisan yang menarik dicermati dari buku ini berkaitan dengan posisi Gus Dur sebagai Presiden RI saat ini. Tulisan pertama ialah "Mencari Perspektif Baru dalam Penegakan Hak-hak Asasi Manusia" (halaman 85), yang dimuat oleh Prisma pada Desember 1979. Tulisan kedua, "Islam dan Militerisme dalam Linfasan Sejarah" (halaman 53), dari Prisma bulan Desember 1980. Tulisan ketiga ialah "Nilai-nilai Indonesia: Apakah Keberadaannya Kini?" (halaman 99), yang diambil dari Prisma bulan November 1981. Tulisan keempat, berupa transkrip dari wawancara, ialah "Jangan Paksakan Paradigma Luar terhadap Agama" (halaman 165), dari Prisma, September 1982.

Membaca keempat tulisan di atas, akan membuat kita -apalagi pembaca yang gemas- seperti sedang menyusuri jejak- jejak langkah Gus Dur kemarin dan hari ini. Lalu muncul sebuah pertanyaan di benak. Apakah gerak-gerik keseharian Gus Dur adalah bagian dari teks-teks yang telah ia tulis, baik teks-teks yang ada di dalam maupun di luar buku ini?

Sekali lagi, dalam konteks ini, empat tulisan di atas sedikit banyak akan membantu para rakyat yang mau tidak mau harus menjadi pengamat Gus Dur sebagai Presiden RI. Sebagaimana dikatakan Hairus Salim HS dalam Kata Pengantar (halaman xviii), bahwa "kumpulan tulisan dariPrisma yang menjadi buku ini, ..., mungkin bisa dijadikan teropong untuk mengerti pemikiran politik Gus Dur, terutama yang menyangkut hubungan agama, ideologi, pembangunan dan negara, integrasi nasional, hak asasi dan perubahan masyarakat". Selain itu, kumpulan tulisan ini bisa juga digunakan untuk menguji apa yang dikatakan Greg 
Barton mengenai "aspek yang paling bisa dipahami" dari Gus Dur yaitu penyeru pluralisme dan toleransi, pembela kelompok minoritas, pencinta kebudayaan Islamtradisional secara kritis, bangga sebagai muslim yang nonchauvinis, serta adalah seorang tokoh spiritual atau figur mistik yang kharismatik, seorang juru harmoni umat Indonesia, dan figur tradisional yang berpikiran modern-liberal (halaman xxii-xxiii).

Benarkah semua itu? Kita lacak dari teks-teks dalam buku ini dan atau dari berbagai permainan politiknya sebagai jejak yang ia tinggalkan, sembari meletakkan nama "Gus Dus" pada ruang penyimpanan subjek untuk sementara waktu.

\section{Tentang Penegakan HAM}

Dalam tulisan "Mencari Perspektif Baru dalam Penegakan HAM' (halaman 85), Gus Dur tidak hanya mengkritik negara-negara pialang HAM seperti Amerika Serikat (dan juga PBB) yang kadang tampil secara munafik, tetapi juga mengkritik gerakangerakan pembelaan HAM oleh kelompok pejuang HAM dan demokrasi. Dalam tulisan ini, tampak bahwa Gus Dur memang tidak menyukai perjuangan HAM dan demokrasi yang dilakukan secara konfrontatif, keras, dan parsial. Dalam perjuangan HAM, menurut Gus Dur, perlu dirumuskan perpaduan antara wawasan liberalistis atas hak yuridis-formal dari perorangan dengan wawasan ekonomis yang menekankan pada pencarian sebab-dasar dari hilangnya hak asasi.

Gus Dur sangat menghitung-hitung korban, walaupun kadang-kadang hal itu diperlukan untuk sebuah investasi politik. Akan tetapi, Gus Dur punya alasan yang berbeda. Dalam melawan rezim militer yang dilakukan oleh mahasiswa, misalnya, pasti akan terjadi kekerasan yang menempatkan mahasiswa sebagai pihak korban yang terbanyak. Lantas, akan terjadi gelombang pembelaan pula atas gerakan mahasiswa itu baik dalam bentuk advokasi hukum maupun kampanye HAM. Secara politis, menurut Gus Dur, "tindakan para pembela mahasiswa itu hanya akan membawa kepada semakin ketatnya cara kerja aparat keamanan atas kerugian masyarakat secara umum", selain "akan menghasilkan pahlawan-pahlawan sensasional kecil yang memprodusir pembelaan pleidoi berjudul hebat-hebat sebagaj sumbangan literatur perjuangan HAM...". Namun demikian, Gus Dur menyadari bahwa metode gerakan itu merupakan rangkaian proses penciptaan kesadaran yang memiliki validitasnya sendiri (halaman 87).

Berangkat dari ulasan di atas, maka kita telah menemukan sebuah jawaban mengapa komentar Gus Dur sangat miring (bahkan menyakitkan) terhadap gelombang demonstrasi mahasiswa awal tahun 1998 hingga Mei 1998 lalu. Walaupun secara politik, dalam konteks ini, perhitungan Gus Dur salah, tetapi kecemasannya itu amat mewakilinya sebagai seorang penganjur harmoni umat. Hal itu pulalah yang membuatnya harus berkayuh di antara dua karang yang sempit, yaitu diantara tokohtokoh yang tidak disukai massa dengan tokoh-tokoh penggerak/pejuang HAM dan demokrasi.

Kalau masih ingat, ketika gerakan mahasiswa dan rakyat Aceh gencar mengkampanyekan "Referendum untuk Aceh", Gus Dur menyebut semua kelompok yang memungkinkan untuk diajak dialog kecuali -sekali lagi- kelompok mahasiswa. Dengan menutup rapat prasangka buruk pada Gus Dur atas sikapnya terhadap kelompok mahasiswa itu, maka kita bisa membuat logika terbalik untuk menyimpulkan bahwa sikap "miringnya" itu muncul jangan-jangan justru karena ia suka dan sayang pada kelompok mahasiswa. 


\section{Tentang Islam dan Militer}

Dalam tulisan "Islam dan Militerisme dalam Lintasan Sejarah" (halaman 53), Gus Dur menunjukkan bahwa sejak permulaan sejarahnya, Islam telah akrab dengan masalah-masalah kemiliteran. Hal itu terjadi karena operasi militer yang bertubi-tubi yang dilancarkan oleh negara-kota Mekah setelah Nabi Muhammad membangun masyarakat muslim di Madinah pada masa sepuluh tahun pertama hidupnya. Dengan demikian, masyarakat Islam pada awal sejarahnya itu sudah harus bekerja keras untuk membangun kekuatan bala tentara (militer) sebagai bagian dari alat pertahanan masyarakat muslim ketika itu. Pada awalnya, bala tentara itu hanya bersifat semacam milisi bersenjata untuk pertahanan dan keamanan. Akan tetapi, peperangan yang terjadi terus-menerus dan dalam waktu yang lama membuat "milisi sipil" itu menjadi tentara reguler yang terlatih dan terkomando. Kondisi ini pulalah yang kemudian menghasilkan kelompok militer profesional dalam masyarakat muslim. Sebuah kondisi logis yang relevan dengan hukum sebabakibat sebagaimana diteorikan dalam teoriteori perang atau teori-teori kemiliteran.

Pada perjalanan sejarah umat Islam selanjutnya, terutama pada masa kekhalifahan, mulai muncul tarik-menarik antara kekuatan sipil dan militer dalam pemerintahan. Sebagai contoh, Khalifah Umar ibn al-Khattab pernah membebastugaskan panglima tertinggi tentaranya yaitu Khalid ibn Walid. Khalid ibn Walid sendiri adalah salah seorang dari sejumlah generasi militer profesional yang teriatih dan terdidik dalam berbagai pengalaman di lapangan pepe rangan. Berkaitan dengan cerita ini, Gus Dur menampilkan dua versi sumber rujukan. Versi pertama menyatakan bahwa Khalid ibn Walid dipecat oleh 'Umar ibn al-Khattab karena penyalahgunaan fasilitas bala ten- tara, yang dalam definisi lain berarti Khalid ibn Walid telah melakukan tindak korupsi (penyalahgunaan wewenang). Versi kedua, menurut Gus Dur, besar kemungkinan tindakan pemecatan itu dilakukan oleh 'Umar ibn al-Khattab dalam rangka memelihara supremasi ibu kota negara atas hirarki markas besar militer di medan pertempuran yang letaknya berjarak ribuan kilometer di dataran rendah Irak. Dengan cara demikian, menurut Gus Dur, supremasi pemerintahan sipil atas bala tentara/militer dipelihara terus-menerus selama operasi penaklukan yang memakan waktu belasan tahun hingga mencapai wilayah Asia Tengah dan Afrika Utara. Hubungan antara Islam dan profesi militer (yang juga sudah memberlakukan sistem gaji) pada waktu itu jelas menunjukkan pola integratif yaitu adanya dukungan pihak militer pada sipil dan aspirasi keagamaan (halaman 58 ).

Dari teks ini dapat disimpulkan bahwa Gus Dur bukanlah orang yang buta pada wacana tentang militer (atau tentang perang) termasuk tentang konftlik sipil dengan militer. Oleh karena itu pula, dapat ditarik sebuah tafsir berkaitan dengan kebijakannya yang lunak pada $A B R I / T N I$ ketika masih dalam Kelompok Ciganjur (sebelum Pemilu 1999) bersama Amien Rais dan Megawati. Juga relevan dengan pola yang diambilnya dalam menangani kasus "perang sipil" di Ambon dan kasus perseteruan ABRI/TNI dengan Angkatan Gerakan Aceh Merdeka (AGAM).

Bahwa bila gempuran yang terusmenerus dilakukan terhadap kelompok sipil bersenjata di Ambon dan Aceh, justru sama saja dengan mendidik sipil itu menjadi milisi yang terlatih dan terkomando secara reguler. Dampak sejarahnya tidak akan pernah mati dan pasti akan melahirkan pelanjut-pelanjut perjuangannya yang tangguh pula. Oleh karena itu, bila problem dasarnya adalah pelanggaran HAM atau kezaliman ke- 
kuasaan pada masa Orde Baru, maka Gus Dur telah menyediakan jalan-jalan ke arah penyelesaian yang berkeadilan. Dalam hal ini, Gus Dur sangat percaya pada kemampuan rakyat dalam mengatasi problemnya sendiri dan oleh karena itu ia menggunakan "teori gantung" (seolah-olah cuek) atas kasus Ambon dan Aceh. Resiko-korban dari teori ini memang kecil, tetapi sifatnya lamban, gradual, dan melelahkan, dan inilah tampak nya warna pertemuan antara ucapan dan tindakan Gus Dur.

\section{Tentang Nilai-nilai Indonesia}

Dalam tulisan "Nilai-nilai Indonesia: Apakah Keberadaannya Kini?" (halaman 99), Gus Dur menyadari adanya pandangan dua kelompok besar tentang nilai-nilai Indonesia. Kelompok pertama, memandang nilaj-nilai Indonesia secara berlebihan sehingga idealisasi nilai-nilai itu sering kekanak-kanakan dan biasanya diwakili oleh aparat pemerintah dan militer. Oleh karena itu, nilai-nilai itu harus diwariskan dan diturunkan melalui lembaga-lembaga formal seperti penataran dan sebagainya (halaman 101). Kelompok kedua, adalah kelompok kritikus sosial yang menyalahkan hidup tradisional yang sudah berlangsung ratusan tahun dan diwarisi dari masa lampau. Nilai-nilai Indonesia yang lahir adalah nilai-nilai yang tidak demokratis, terbelakang dalam segala bidang, dan menimbulkan kemutlakan kekuatan politik dari elit kekuasaan yang memperoleh penghasilan yang tidak imbang dari kedudukan politis yang mereka peroleh (halaman 99 ). Kelompok ketiga, ialah kelompok akademisi yang memandang nilai-nilai Indonesia dari pembuktian yang diikuti kajian empiris dari berbagai disiplin ilmu. Akan tetapi, menurut Gus Dur, pendekatan kelompok ini (berdasarkan pemusatan pada sejumlah nilai atau orientasi) sering kali menghasilkan se- suatu yang menghindari pertanyaan pokoknya, yaitu apabila konflik yang dibutuhkan untuk mengarahkan kembali sebuah nilai yang dianggap negatif terhadap pembangunan, agar mengikuti jejak nilai lain yang dianggap positif bagi pembangunan (halaman 102-103). Kelemahan pendekatan ini karena terlalu ketat pada model pengklasifikasian atau penspesialisasian sehingga banyak hal yang mungkin terlalu disederhanakan.

Dalam tulisannya ini Gus Dur menunjukkan pembelaannya pada nilai-nilai tradisional dan pluralisme etnis Indonesia, yang secara historis menjadi bagian dari proses pembentukan kesadaran "kebangsaan modern". Untuk memperkuat alasannya itu, Gus Dur mencontohkan lahimya organisasiorganisasi pemuda kedaerahan dan gerakan Islam yang semula lokal menjadi nasional. Dalam sejumtah argumennya dalam tulisan ini, Gus Dur ingin menampilkan perspektif baru dalam memandang "nilainilai Indonesia" sekaligus mengoreksi apa yang tidak enak dari ketiga pandangan yang ada di atas. Gus Dur menyatakan:

... yang "paling Indonesia" diantara semua nilai yang diikuti oleh warga bangsa ini adalah pencarian tak berkesudahan akan sebuah perubahan sosial tanpa memutuskan sama sekali ikatan dengan masa lampau. Kita dapat saja menamainya sebagai pencarian harmoni, walaupun dengan begitu bersikap tidak adil terhadap pencarian besar dengan peranan dinamisnya dalam pengembangan cara hidup bangsa dan menyalurkannya ke jalan baru tanpa menghancurkan jalan lama, semuanya dalam proses yang berurutan. Nilai-nilai lain yang bersumber pada pencarian ini, atau yang dikembangkan untuk menunjangnya, dengan demikian merupakan gugusan terbesar nilai-nilai Indonesia dewasa ini, berupa 
solidaritas sosial yang didasarkan pada rasa kebangsaan tanpa mengucilkan getaran rasa impulsif untuk mengutamakan kelompok-kelompok yang lebih sempit (kesetiaan suku dan seterusnya); nilai-nilai yang menampilkan watak kosmopolitan, yang masih diimbangi oleh rasa keagamaan yang kuat; ... (halaman 109).

Sekarang, justru karena telah menjadi Presiden, maka spektrum pendengaran dan penglihatan Gus Dur meluas melampaui geografis nusantara. Oleh karena itu, Gus Dur telah menjadi apa yang dia inginkan yaitu "menjadi orang Indonesia" yang bisa melihat keragaman nusantara atau nilainilai Indonesia dari Jakarta, atau dari belahan dunia lain.

Dengan demikian, pada satu sisi, Gus Dur diuji apakah masih membela pluralisme dan kearifan-tradisionalisme yang selama ini ia kritisi dan jalani; dan pada sisi lain, ia harus mengambil keputusan-keputusan atau kebijakan politik praktis yang mungkin bisa/harus berbenturan dengan kenyataan pluralisme dan kearifan-taradisional itu.

"Nilai-nilai Indonesia", kini, ada di tangan Gus Dur -karena ia Presiden-, tetapi sebagian masih dalam bentuk yang terkubur oleh kezaliman rezim masa lalu, dan sebagian lagi sedang remuk-redam di depan matanya oleh pertikaian internal.

\section{Tentang Paradigma Luar dan Agama}

Dalam tulisan "Jangan Paksakan Paradigma Luar terhadap Agama" (halaman 165), Gus Dur melihat setiap agama selalu berada dalam dua kutub ketegangan dinamis yaitu 1) ketegangan karena dinamika dan pluralitas pemahaman internal; dan 2) ketegangan karena dinamika dan pluralitas eksternal agama-agama yang ada.
Melalui tulisan ini, tercermin cara pandang Gus Dur yang tidak ingin melihat agama ditempeli oleh tafsir "paradigama dari luar". Gus Dur mengambil contoh "Teologi Pembebasan" yang merupakan paduan antara kesadaran Katolik dan teoriteori Marxian. Dalam wacana Islam, Gus Dur mencontohkan bahwa ideologi ke sahidan para mullah di Iran yang diperjuangkan Ali Shariati, hilang semuanya dalam waktu dua tahun. Makna "Revolusi Islam" itu pun tidak ada lagi, kecuali penguatan institusi para mullah atau institusi "Republik Islam" yang kemudian menjadi konservatif. Lalu, "Di mana pembebasan nya?" tanya Gus Dur. Menurut Gus Dur, dalam proses perubahan sosial, agama hanya berfungsi sebagai suplementer dan hanya menyediakah sarana untuk proses perubahan itu. Jadi, bukan agama yang membuat perubahan dan juga bukan penentu perubahan. Bila agama yang menjadi penentu, maka agama itu menjadi duniawi dan bahayanya: bisa mengundang sikap represif. "Agama menjadi represif untuk mempertahankan dirinya" (halaman 167).

Kritik Gus Dur ini menarik karena berguna untuk meneropong gerakan-gerakan Islam-politik yang ada di luar negeri maupun di Indonesia. Mengapa menarik? Justru karena Gus Dur meyakini bahwa agama memang mempunyai dampak pembebasan. Akan tetapi, menurut Gus Dur, dampak pembebasan itu tidak revolusioner, malah lambat dan jangkauannya jauh ke depan dalam jangka panjang. Artinya, pembebasan agama dalam pandangan Gus Dur adalah pembebasan atau pergerakan_secara kultural. Karena sifat pembebasannya yang lambat itulah, maka banyak umat yang tidak sabar dan kemudian tergoda pada paradigma-paradigma dari luar agama yang iramanya sangat jauh berbeda. Dalam tulisannya ini, Gus Dur 
tidak menjelaskan "paradigma luar" yang dimaksudnya itu apa. Akan tetapi, karena ia juga mencontohkan gerakan "Teologi Pembebasan" di Amerika Latin, maka dapat kita tebak bahwa paradigma yang dimaksudnya itu ialah semacam teori-teori radikal, ekstremisme agama, fundamentalisme, atau teori-teori "kiri" (Marxian).

Sekali lagi tampak kalau Gus Dur percaya pada kekuatan rakyat dalam mentransformasikan dirinya terhadap berbagai perubahan. Indikasinya tersurat pada pernyataannya yang mengatakan bahwa proses pembebasan itu paradigmanya jangan dari agamawan sebab akan berbahaya. Gus Dur takut kalau-kalau agamawan itu justru melakukan pembebasan karena semata melayani kepentingan ototritasnya sendiri. Atau dalam bahasa Gus Dur, agamawan itu mendukung pembebasan dengan "otoritas surga". Poin ini menjadi pertanyaan besar karena menjadi otokritik tak terduga buat Gus Dur yang sekarang berada di pucuk pimpinan negara, selain juga karena ia ikut bermain di Partai Kebangkitan Bangsa.

Pada bagian ini, agaknya memang harus hati-hati menilai Gus Dur. Bagaimanapun, kritiknya pada gerakan agama yang bertujuan semata-mata politik (kekuasaan), menjadi sangat penting. Akan tetapi, juga tidak ada garansi bila untuk membuat perubahan dan pembebasan hanya sematamata berpijak pada prinsip sekuleritas. Pada bagian inilah Gus Dur sering terlibat polemik tajam dengan sebagian kelompok muslim Indonesia, bahkan hingga hari ini.

Akhirnya, rakyat atau siapa pun tidak perlu cemas dan merasa berdosa bila tidak bisa memahami, memaklumi, atau tidak bisa menjadi pengamat yang baik dan akurat terhadap Gus Dur. Mengapa? Karena Gus Dur sering berujar: "Itu saja kok repot!•

Mulyadi J. Amalik, - alumnus Fakultas Filsafat UGM. 